\title{
Sensitivity of S49.1 cells to anti-CD95 (Fas/Apo-1)-induced apoptosis: effects of CD95, bcl-2 or bcl-x transduction
}

\author{
H. Elizabeth Broome $e^{1,3}$, Catherine M. Dargan', \\ Thomas Brunner ${ }^{2}$ and Douglas R. Green ${ }^{2}$

\footnotetext{
1 Department of Pathology, University of California, San Diego, CA 92093, USA

2 La Jolla Institute for Allergy and Immunology, La Jolla, CA 92121, USA

3 corresponding author: tel: (619)534-5216; fax: (619)534-7415;

e-mail: ebroome@ucsd.edu
}

Received 21.3.97; revised 24.7.97; accepted 12.9.97

Edited by J.C. Reed

\begin{abstract}
T lymphocytes have variable sensitivity to anti-CD95 which does not correlate closely with the level of CD95 expressed. To investigate this phenomenon, we screened murine $T$ lymphocyte cultures for their sensitivity to anti-CD95. Subclones of the $\mathbf{S} 49.1$ cells showed widely variable sensitivity to anti-CD95 but similar levels of CD95. The resistant clones became sensitive after treatment with actinomycin D suggesting that they expressed resistance protein(s) with a high turnover relative to the CD95 apoptosis induction machinery. Our data suggest that the resistance protein(s) are not Bcl-2, Bcl-x, Fap-1 or Bag-1. Forced, increased expression of CD95 made most of the resistant cells more sensitive, but some remained resistant suggesting that the expression of the resistant protein(s) is heterogeneous and that increased CD95 levels does not always overcome the resistance.
\end{abstract}

Keywords: CD95; Fas; T-cell; lymphocyte; apoptosis

Abbreviations: TCR, T cell receptor; AICD, activation induced cell death; MFI, mean fluorescence intensity

\section{Introduction}

CD95, a member of the tumor necrosis factor receptor (TNFR) superfamily of cell surface receptors, can transduce an apoptotic death signal after interaction with ligand or antiCD95. Mice (Watanabe-Fukunaga et al, 1992) and humans (Rieux-Laucat et al, 1995) with defects in the expression of CD95 develop a lymphoproliferation syndrome (Ipr) with similarities to Systemic Lupus Erythematosis. T cells from mice are resistant to apoptosis induced by reactivation through the T cell receptor (TCR) (Russell et al, 1993). Also, CD95-Ig chimeric proteins can inhibit this activation induced cell death (AICD) in T cells (Brunner et al, 1995) suggesting that it is often mediated through CD95. These findings suggest that CD95 is important for limiting the T cell immune response.
Resting T cells express very little CD95. Within $24 \mathrm{~h}$ after activation, murine and human $\mathrm{T}$ cells upregulate CD95 expression (Owen-Schaub et al, 1992; Klas et al, 1993; Nishimura et al, 1995; Tucek-Szabo et al, 1996). However, not all activated T cells that express CD95 are sensitive to anti-CD95 induced apoptosis. Human T cells only become sensitive several days after activation, but the sensitivity of the recently activated $T$ cells can be increased with actinomycin treatment (Klas et al, 1993). Many CD95 expressing cell lines demonstrate anti-CD95 sensitivity only with actinomycin or cycloheximide treatment (Itoh et al, 1991; Tewari and Dixit, 1995). These findings suggest that there are protein(s) that inhibit the CD95 induced apoptosis and that these protein(s) have a high turnover relative to the CD95 apoptosis induction machinery. In this study, we have investigated the role of CD95 levels and the expression of known inhibitors of apoptosis in regulating the sensitivity of S49.1 T cells clones to anti-CD95 induced apoptosis.

\section{Results}

$\mathrm{T}$ lymphocytes that express similar levels of CD95 are profoundly different in their sensitivity to anti-CD95 induced apoptosis. To identify a murine cell culture model to explore this phenomenon, we screened primary cultures of Con $A$ activated splenic T cells, the murine hybridoma 2B4 (Brunner et al, 1995), and murine T lymphocyte cell lines SL12.4 (Weinroth et al, 1985), CTLL-2 (ATCC, Rockville, MD) and S49.1 (ATCC) cells for their sensitivity to anti-CD95. Of these cells, only the S49.1 cells displayed sensitivity to anti-CD95 (Figure 1). About $15-20 \%$ of the S49.1 cells underwent apoptosis after anti-CD95 treatment, and this percentage was maximal at between 0.5 and $1 \mu \mathrm{g} / \mathrm{ml}$ anti-CD95 (Figure 2). Also, the percentage of apoptotic cells reached a plateau at about $24 \mathrm{~h}$ after treatment with anti-CD95.

\section{Clones of the S49.1 cells have variable but stable sensitivity to anti-CD95}

Since only a minority of the $\mathbf{S} 49.1$ cells were susceptible to anti-CD95 induced apoptosis, we cloned the S49.1 cell line, and tested 8 subclones for their sensitivity to anti-CD95. Two clones (numbers 4 and 5) were much more sensitive to antiCD95 than the original cell line, two were quite resistant (numbers 2 and 6), and the rest showed similar sensitivity to the original cell line (Table 1). However, even the most resistant clone 2 showed significant increased apoptosis after treatment with anti-CD95 $(P<0.05)$. The relative sensitivity and resistance of these clones remained stable for at least 2 months of continuous culture.

To determine why these S49.1 clones had such different sensitivity to anti-CD95, we first investigated the level of CD95 expressed by the resistant and sensitive clones. The expression of CD95 is slightly higher in the sensitive clones 
by flow cytometry suggesting that the sensitivity is related to the level of CD95 expressed (Figure 3). However, the level of CD95 is probably not the only factor since, in the presence of actinomycin, both the resistant and the sensitive clones became more sensitive to anti-CD95 (Figure 4). The resistant clone S49.1.2 showed increased sensitivity by about $12 \mathrm{~h}$ with actinomycin and anti-CD95, but by $24 \mathrm{~h}$ with actinomycin plus anti-CD95, this clone showed 2.6-fold more apoptosis than the cells treated with just actinomycin and almost the same level of apoptosis as the sensitive clone S49.1.4 treated with anti-CD95 alone.

This increase in the sensitivity of the resistant clone to anti-CD95 induced apoptosis in the presence of actinomycin suggests that these resistant cells receive apoptosis inducing signals through CD95. Also, since the inhibition of transcription by actinomycin increases the susceptibility of

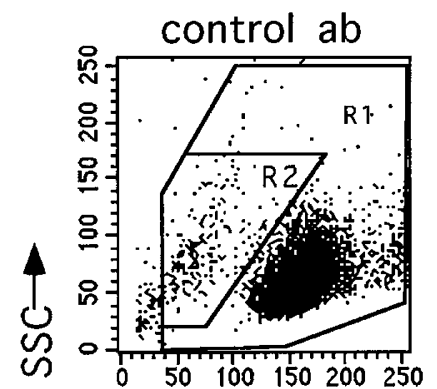

\section{FSC-}

\% apoptosis: $2 \%$

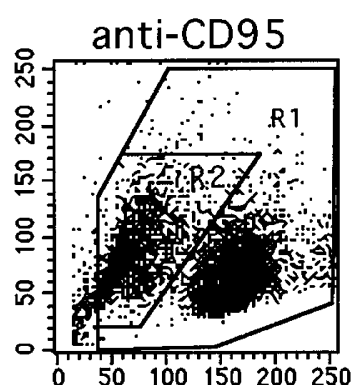

$21 \%$
Figure 1 Induction of apoptosis in the $S 49.1$ cells by anti-CD95. $1 \times 10^{5}$ S49.1 cells were cultured with $1 \mu \mathrm{g}$ anti-mouse CD95, clone Jo2, or control hamster IgG in $1 \mathrm{ml}$ of a 48 well culture plate for $18 \mathrm{~h}$. Flow cytometry analysis demonstrated apoptosis by the characteristic reduction in forward light scatter (FSC) and increase in side scatter (SSC) (Swat et al, 1991). The per cent apoptosis was determined by dividing the number of events in region 2 (R2) by the number of events in region 1 (R1) and multiplying by $100 \%$ these cells, the resistant cells probably have a resistance protein that is relatively labile compared to the machinery necessary to induce apoptosis after anti-CD95 treatment.

\section{Increased levels of $\mathrm{Bcl}-2$ or $\mathrm{Bcl}-\mathrm{x}$ decrease dexamethasone sensitivity but do not affect sensitivity to anti-CD95}

As a preliminary step to identify the protein(s) that render the S49.1 cells resistant to anti-CD95, we determined the levels of $\mathrm{Bcl}-2, \mathrm{Bcl}-\mathrm{x}$, and Bag-1. These proteins are known to affect

Table 1 Percent apoptosis in cultures of S49.1 clones exposed to anti-CD95. S49.1 cells were cloned by limiting dilution and tested for sensitivity as described in Figure 1

\begin{tabular}{|c|c|c|c|}
\hline & $\%$ Ap & tosis & \\
\hline Clone & control & & \\
\hline number & antibody & anti-CD95 & \\
\hline Experiment 1 at time & & & \\
\hline 1 & 1.5 & 21.0 & \\
\hline 2 & 0.9 & 2.2 & \\
\hline 3 & 4.2 & 12.4 & \\
\hline 4 & 2.2 & 63.0 & \\
\hline 5 & 4.2 & 47.0 & \\
\hline 6 & 1.0 & 8.2 & \\
\hline 7 & 1.2 & 31.3 & \\
\hline 8 & 0.8 & 24.0 & \\
\hline Experiment 2 at 1 wee & & & \\
\hline 2 & 1.2 & 2.8 & \\
\hline 4 & 2.5 & 55.5 & \\
\hline 5 & 2.0 & 16.1 & \\
\hline 6 & 0.7 & 4.1 & \\
\hline Experiment 3 at 8 wee & & & \\
\hline 2 & 2.2 & 3.7 & \\
\hline 4 & 3.8 & 50.1 & \\
\hline Experiment 1,2 and 3 & Mear & S.D.) & $\begin{array}{c}P \text { value } \\
\text { (paired, } 2 \text { tail) }\end{array}$ \\
\hline 2 & $1.4(0.7)$ & $2.9(0.8)$ & 0.0018 \\
\hline 4 & $2.8(0.8)$ & $56.2(6.5)$ & 0.0061 \\
\hline
\end{tabular}
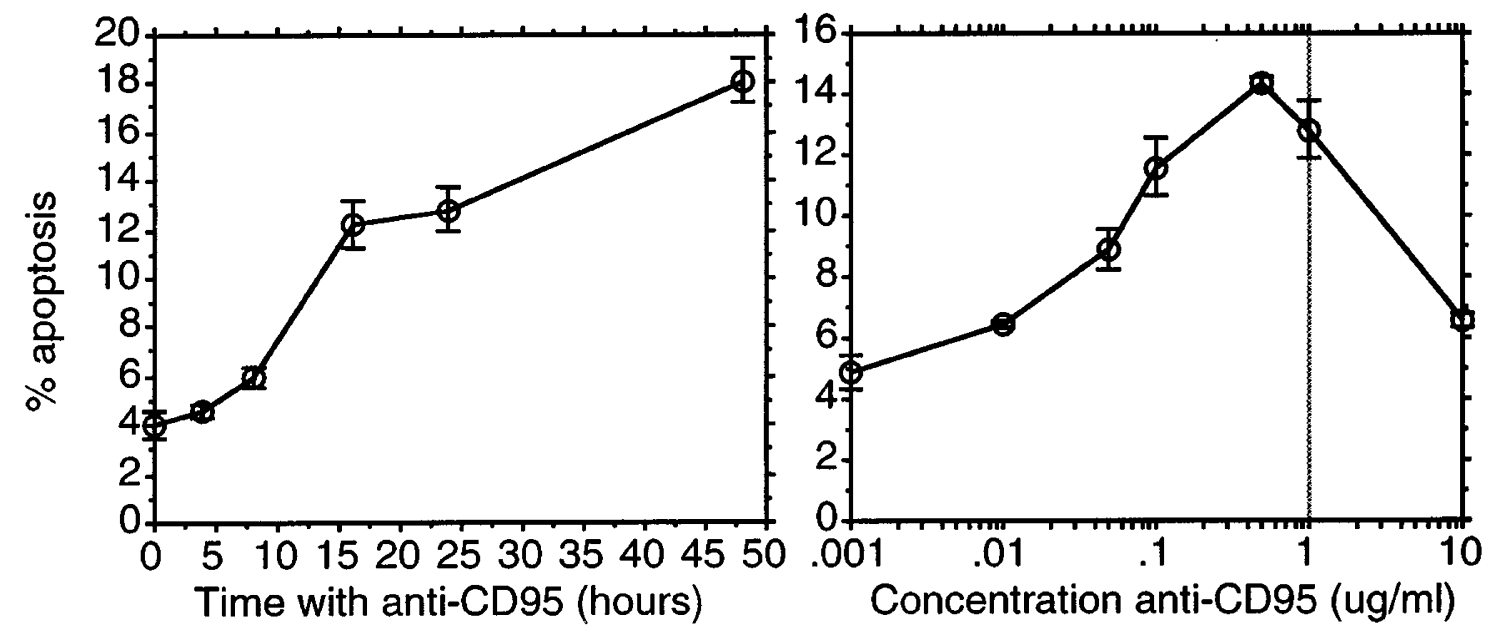

Figure 2 Time course and concentration dependence of anti-CD95 induced apoptosis. S49.1 cells were cultured with $1 \mu \mathrm{g} / \mathrm{ml}$ anti-CD95 for the indicated time or with the indicated concentration of anti-CD95 for $18 \mathrm{~h}$. The per cent apoptosis was determined as described for Figure 1 
S49.1.2

(resistant)

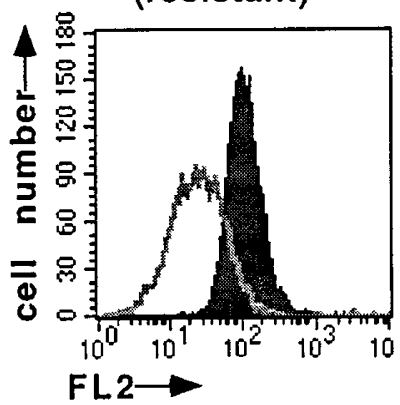

S49.1.4

(sensitive)

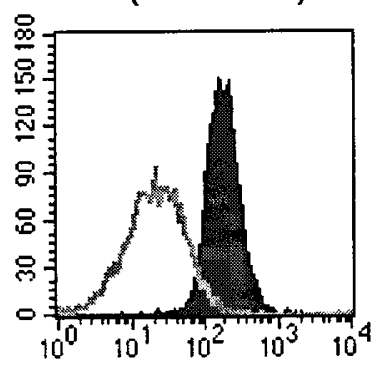

Figure 3 Expression of CD95 in S49.1 clones by flow cytometry. The indicated clones and cells were stained with phycoerythrin (PE)-conjugated hamster IgG (single line peak) or PE-conjugated anti-CD95, clone Jo2 (solid peak)

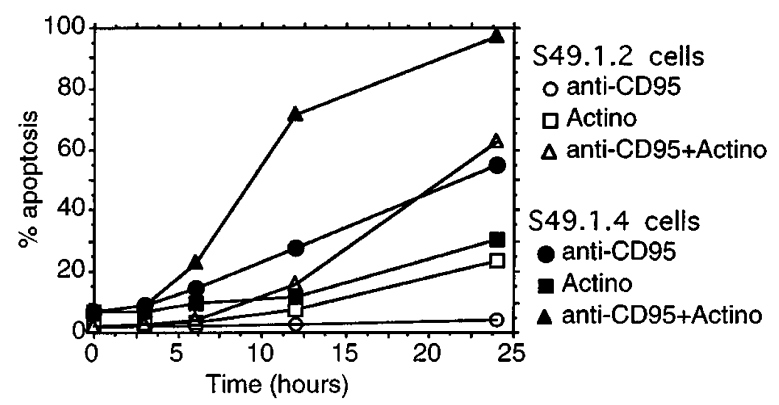

Figure 4 Effect of actinomycin D on the sensitivity of S49.1 clones to antiCD95 induced apoptosis. S49.1.2 (resistant) or S49.1.4 (sensitive) cells were cultured with either anti-CD95, actinomycin D at $0.5 \mu \mathrm{g} / \mathrm{ml}$, or actinomycin D plus anti-CD95. At the indicated hours, the cells were tested for per cent apoptosis as described for Figure 1

the sensitivity of $T$ cells to apoptosis inducing environments. Forced expression of $\mathrm{Bcl}-2$ or $\mathrm{Bcl}-\mathrm{x}$ can inhibit the apoptosis of lymphocytes under many conditions including exposure to anti-CD95, but in some cells, there is no apparent effect of bcl2 transduction on the sensitivity of cells to anti-CD95 (Itoh et al, 1993; Boise et al, 1995; Chiu et al, 1995). Resistant and sensitive clones expressed very low levels of Bcl-2 protein (Figure 5). In contrast, resistant clones had slightly higher levels of $\mathrm{Bcl}-\mathrm{x}$ protein than sensitive clones. Bcl-2 interacts with a protein called Bag-1, and increased Bag-1 expression can synergise with $\mathrm{Bcl}-2$ to inhibit anti-CD95 induced apoptosis (Takayama et al, 1995). However, the level of Bag-1 protein appeared similar in all the clones (Figure 5). Fap-1 interacts with CD95, and increased levels of this protein can inhibit anti-CD95 induced apoptosis (Sato et al, 1995). However, no fap-1 RNA is detectable in any of the S49.1 clones as measured by a sensitive RNAse protection assay (Figure 6).

Since Bcl-x has apoptosis inhibiting activity and since a modest elevation of $\mathrm{Bcl}-\mathrm{x}$ protein level correlated with increased resistance to anti-CD95 induced apoptosis in the S49.1 clones, we determined whether transduction of bcl-x or bcl-2 affected the sensitivity of the S49.1.4 cells to anti-
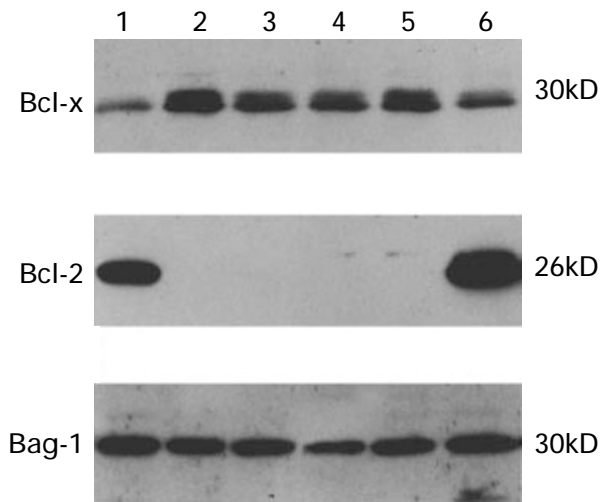

Figure 5 Immunoblots showing $\mathrm{Bcl}-\mathrm{x}, \mathrm{Bcl}-2$, and Bag-1 protein levels. Lane 1, CTLL-2; Lane 2, S49.1.2 (resistant); Lane 3, S49.1.4 (sensitive); Lane 4, S49.1.5 (sensitive); Lane 5, S49.1.6 (resistant); Lane 6, splenic T cells activated with Con A plus IL-2 for 6 days

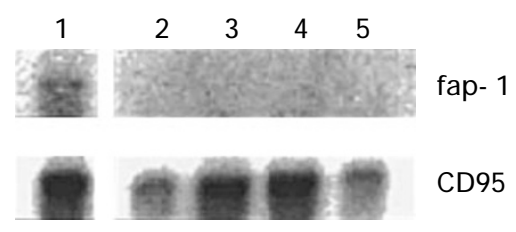

Figure 6 RNAse protection assay showing the absence of fap-1 RNA and levels of CD95 RNA. Lane 1, splenic T cells activated with anti-CD3 (2C11, $2 \mu \mathrm{g} / \mathrm{ml}$ coated on tissue culture plates) for $48 \mathrm{~h}$; Lane 2, S49.1.2 (resistant); Lane 3, S49.1.4 (sensitive); Lane 4, S49.1.5 (sensitive); Lane 5, S49.1.6 (resistant). The protected fragments are $700 \mathrm{bp}$ for fap- 1 and $542 \mathrm{bp}$ for CD95

CD95 induced apoptosis. Using the retroviral vector pSAMEN (Treisman et al, 1995), we infected the S49.1.4 cells with constructs containing either no additional genes, the human bcl-2 cDNA or the human bcl-x cDNA.

After infection, the G418 resistant cells were then cloned. Five clones expressing only the pSAMEN (control), seven clones expressing the bcl-2 gene, and 9 clones expressing the bcl-x gene were tested for their sensitivity to anti-CD95 and $10^{-6} \mathrm{M}$ Dexamethasone (Figure 7). All of the clones expressed similar levels of the transduced gene (data not shown). By densitometric scanning of the immunoblot exposed X-ray film, the level of $\mathrm{Bcl}-\mathrm{x}$ protein increased about 50 -fold. The fold increase in the Bcl-2 protein was difficult to calculate since the level of protein in the control transduced cells was almost undetectable, but the level of Bcl-2 protein level in the bcl-2 transduced cells was similar to that of the RS11846 cell line that has a $t(14 ; 18)$ translocation. Just as reported previously (Miyashita and Reed, 1992), we found that the S49.1 cells are made resistant to Dexamethasone induced apoptosis by the forced expression of bcl-2 (Figure 7). Bcl-x had a very similar ability to confer resistance to Dexamethasone. However, the forced expression of neither gene had any affect on the sensitivity of S49.1.4 cells to anti-CD95 induced apoptosis suggesting that differences in their level of expression is not causing the observed differences in sensitivity of the S49.1 clones to anti-CD95. 


\section{Increased levels of CD95 increase the sensitivity of most but not all clones}

To more completely investigate the effect of CD95 levels on anti-CD95 sensitivity, we determined whether a resistant clone could be made more sensitive with increased CD95 expression. We infected the resistant S49.1 clone (S49.1.2) with a retroviral vector containing the murine CD95 CDNA, and 10 clones were characterized for their expression of CD95 and their sensitivity to anti-CD95. All of the clones showed higher CD95 expression and most showed increased sensitivity to anti-CD95. One clone showed higher CD95 expression but little if any increased sensitivity (S49.1.2C.1). Just as with the parent clone, this retrovirally transduced clone become more sensitive to anti-CD95 after treatment with actinomycin (Figure 8). Treatment of this clone with anti-CD95 alone for $18 \mathrm{~h}$ resulted in about $5 \%$ apoptosis while treatment with both anti-CD95 plus actinomycin D resulted in over $30 \%$ apoptosis. The S49.1.2C.6 and the S49.1.2C.9 clones both expressed similar levels of CD95 as the S49.1.2C.1, but they were both more sensitive to anti-CD95 alone showing 30$40 \%$ apoptosis after $18 \mathrm{~h}$ of treatment. Also, the resistant

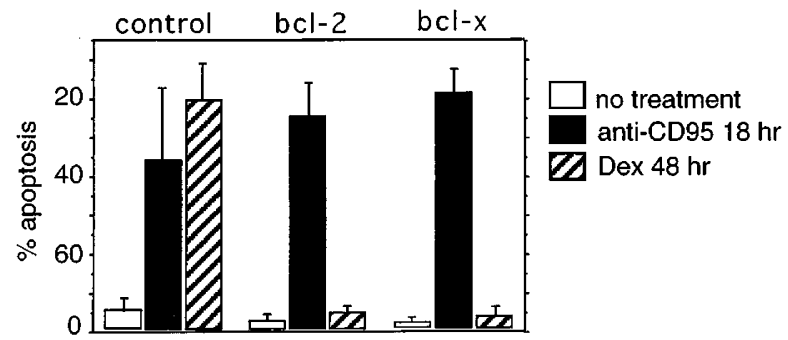

Figure 7 Effects of bcl-2 or bcl-x transduction on $\mathrm{S} 49.1 .4$ sensitivity to antiCD95 or Dexamethasone induced apoptosis. S49.1.4 cells were transduced with the pSAMEN retroviral vector containing no additional insert (control) or inserts with either the human bcl-2 cDNA or the human bcl-x cDNA. Clones of these transduced cells that were G418 resistant were tested for their spontaneous level of apoptosis (open bars), their sensitivity to anti-CD95 as described in Figure 1 (filled bars), and their sensitivity to glucocorticoids by adding $10^{-6} \mathrm{M}$ Dexamethasone for $48 \mathrm{~h}$ (hatched bars)

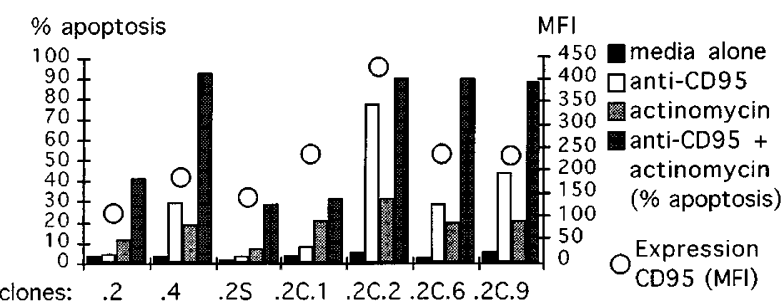

Figure 8 CD95 expression levels and anti-CD95 sensitivity of S49.1 clones and S49.1.2 cells transduced with CD95. S49.1.2 cells (see Table 1) were infected with the retrovirus SAMEN alone $(0.2 S)$ or with the murine CD95 cDNA (0.2C). Clones of these CD95 transduced cells are labeled C.1, C.2, C.6 and C.9. Per cent apoptosis was determined as described for Figure 1. CD95 expression was measured by flow cytometry as described for Figure 3. MFI, Mean Fluorescence Intensity. The coefficient of variation for the apoptosis assays were less than $5 \%$ for triplicate measurements within each experiment, and the data are representative of three separate experiments clone S49.1.2C.1 expressed higher levels of CD95 than the sensitive S49.1.4 cells that were not retrovirally transduced. Therefore anti-CD95 sensitivity does not correlate completely with the level of CD95 expressed.

\section{Discussion}

Our discovery that clones of the murine T cell line S49.1 have variable sensitivity to anti-CD95-induced apoptosis provides useful tools to study CD95 signaling. To date, the only other T cell lines reported to be sensitive to anti-CD95 are the human $\mathrm{T}$ cell leukemia lines Jurkat, CEM, and Molt (Trauth et al, 1989), and these cell lines are homogeneously sensitive (data not shown). The heterogeneity of sensitivity and the ease of cloning by limiting dilution make the $S 49.1$ cells ideal for further genetic analysis of the regulation of anti-CD95 sensitivity.

Other murine cell lines have been reported to be sensitive to CD95-mediated apoptosis but not sensitive to anti-CD95. CD95-mediated apoptosis of $\mathrm{T}$ cells include apoptosis resulting from anti-CD95 treatment, from CD95 interacting with its ligand, and from some forms of activation induced cell death (AICD). Recent articles have demonstrated that activating $T$ cell hybridomas through the $T$ cell receptor (TCR) induces CD95 expression, CD95 ligand expression, and subsequently cell death. The AICD in these cells is mediated through CD95 since blocking the interaction of CD95 with the CD95 ligand inhibits AICD (Brunner et al, 1995). However, it is not known whether the TCR signaling also induces a decrease in resistance protein(s). Also, not all AICD is mediated through CD95; TNF mediates the AICD of most $\mathrm{CD}^{+} \mathrm{T}$ cells, whereas CD95 mediates the AICD of most CD4 ${ }^{+} \mathrm{T}$ cells (Zheng et al, 1995).

Our data confirm accumulating evidence that sensitivity of $\mathrm{T}$ cells to CD95-mediated apoptosis depends not only upon the levels of CD95 and exposure to CD95 ligand, but also on the expression of protein(s) that render the cells resistant to CD95-mediated apoptosis. Variable expression of resistance protein(s) in clones of the S49.1 cells probably exists since some clones are resistant to antiCD95 even when they express higher levels of CD95 than sensitive clones, and all of the resistant clones show increased sensitivity after treatment with actinomycin D. Also, because actinomycin treatment causes the resistant clones to become more sensitive to anti-CD95, it is unlikely that these resistant clones are missing parts of the effector pathway such as FADD or FLICE (Muzio et al, 1996).

Our data also indicate that the resistance protein(s) in the S49.1 cells probably are not Bcl-2, Bcl-x, Fap-1 or Bag1 since forced expression of $\mathrm{Bcl}-2$ or $\mathrm{Bcl}-\mathrm{x}$ does not render the sensitive cells resistant to anti-CD95 and the levels of fap-1 RNA and $\mathrm{Bcl}-2, \mathrm{Bcl}-\mathrm{x}$, and Bag-1 protein were similar in the resistant and sensitive clones. There is some controversy in the literature about whether increased Bcl2 or Bcl-x levels effectively blocks CD95 mediated apoptosis. One argument against bcl-2 or bcl-x having significant activity to prevent CD95-mediated apoptosis is that mice transgenic for $b c l-2$ or $b c l-x$ do not exhibit features of the lymphoproliferative (lpr/lpr) syndrome that 
occurs in mice having defective CD95 expression (Chao et al, 1995). However, there have been reports that the forced expression of bcl-2 (Itoh et al, 1993) or bcl-x (Boise et al, 1995) can reduce the sensitivity of some $T$ cells to antiCD95 induced apoptosis. Possible explanations for why we do not see a similar effect in the S49.1 cells include: (1) There may be a difference between the cell lines studied; (2) The level of bcl-2 and bcl-x expression may not be sufficient in our model. However, since the level of $\mathrm{Bcl}-\mathrm{x}$ protein in the retrovirally infected clones is about 50 -fold higher than in the non-infected, resistant clone S49.1.2 (data not shown), the slightly higher level of $\mathrm{Bcl}-\mathrm{x}$ protein in the S49.1.2 clone compared to the other sensitive clones does not explain the resistance of the S49.1.2 cells to antiCD95.

Other inhibitors of apoptosis exist besides those investigated in this article. However, none of these are known to exist in T cells and have activity against CD95 mediated apoptosis. One inhibitor of special relevance to CD95 mediated apoptosis is CrmA, a cysteine protease inhibitor from the cowpox virus (Enari et al, 1995). CrmA inhibits activation induced cell death but has little effect on Dexamethasone-mediated cytotoxicity in a T cell hybridoma (Memon et al, 1995). This finding suggest that distinct apoptosis signaling pathways exist with differential sensitivity to cysteine protease inhibitors versus $\mathrm{Bcl}-2$ (or family members) and confirms that proteases are involved in intracellular signaling for apoptosis.

These S49.1 clones with variable sensitivity to anti-CD95 should be useful for identifying the genes that code for the resistance protein(s). Differential display or subtractive hybridization techniques could be used to identify mRNA with higher levels in the resistant cells than the sensitive cells. Alternatively, expression libraries of cDNA from the resistant cells could be screened for clones that increase the resistance of the sensitive cells.

\section{Materials and Methods}

\section{Cell culture}

S49.1 and COS cells were from the ATCC, Rockville, MD and were cultured as recommended.

\section{Antibodies}

The antibodies used for immunoblotting or flow cytometry were the Jo2 anti-mouse CD95 and the 3F11 monoclonal anti mouse $\mathrm{Bcl}-2$ (Pharmingen, San Diego, CA), the mouse monoclonal M887 antihuman Bcl-2 (Dako, Glostrup, Denmark), and the polyclonal rabbit anti-Bcl-x (Krajewski et al, 1994) and anti-Bag-1 (Takayama et al, 1995; Sato et al, 1995) raised to synthetic peptides (laboratory of John C. Reed, Burnham Institute, La Jolla, CA).

\section{DNA constructs}

The $910 \mathrm{bp} E c o R I$ fragment containing the full human cDNA for bcl-2 (Tsujimoto and Croce, 1986) or the 926 bp EcoRI fragment containing the human bcl-x cDNA (Boise et al, 1993) or the $1.3 \mathrm{Kbp}$ EcoRI fragment of the murine CD95 cDNA (Rouvier et al, 1993) were subcloned into the Notl to Xhol site of pSAMEN (Treisman et al, 1995), a retroviral vector based upon the Moloney murine leukemia virus, using standard molecular biology techniques.

\section{Retroviral transduction of S49.1 cells}

Retrovirus stocks were produced by transient co-transfection of a $10 \mathrm{~cm}$ plate of $25 \%$ confluent COS cells with both $10 \mu \mathrm{g}$ of SVpsi-EMLV helper virus DNA (Landau and Littman, 1992) plus $10 \mu \mathrm{g}$ of the pSAMEN (Treisman et al, 1995) vector containing the cDNA of interest. Between 24-48 $\mathrm{h}$ after the COS cells were transfected with the calcium phosphate technique (Kingston, 1990), culture supernatant was collected, filtered through $0.45 \mu \mathrm{m}$ filters and added to the S49.1 cells at $2 \times 10^{5} / \mathrm{ml}$ with $8 \mu \mathrm{g} / \mathrm{ml}$ polybrene (Sigma). After $1 \mathrm{~h}$, the cells were diluted with media to $5 \times 10^{4} \mathrm{ml}$. After 2 days of culture, the cells were split into media with $1 \mathrm{mg} / \mathrm{ml} \mathrm{G} 418$ (Life Technologies, Gaithersburg, MD). After 3 days in G418 media, the cells were cloned by limiting dilution into media with $1 \mathrm{mg} / \mathrm{ml} \mathrm{G} 418$.

\section{Immunoblot}

Immunoblots were performed as previously described (Broome et al, 1995). Briefly, $20 \mu \mathrm{g}$ of post-nuclear, detergent lysates was loaded in each lane and run on a $12 \%(\mathrm{w} / \mathrm{v})$ SDS-PAGE gel using the Laemmli method. The blots were blocked in PBS with $0.1 \%(\mathrm{v} / \mathrm{v})$ Tween-20, 5\% $(\mathrm{w} / \mathrm{v})$ skim dried milk and $2 \%(\mathrm{w} / \mathrm{v})$ BSA for $1 \mathrm{~h}$; then blots are incubated with a dilution of the appropriate primary antibody in the blocking solution. After washing, an appropriate dilution of the biotinylated secondary antibody (affinity purified goat anti-rabbit IgG or goat anti-mouse IgG, Vector Laboratories, Burlingame, CA) was added. Then the blot is washed and developed as described in the ECL Luciferase system product insert (Amersham, Buckinghamshire, UK).

\section{RNAse protection assay}

RNAse protection assay for fap-1 and CD95 was performed as described previously (Brunner et al, 1995), using a commercial RPA kit (Ambion, Austin, TX). Briefly, Bluescriptll (Stratagene) vectors containing a $700 \mathrm{bp}$ EcoRl fragment of murine fap-1 cDNA ( $T$ Sato and JC Reed, unpublished) (Sato et al, 1995) or a 1480 bp EcoRI fragment of murine CD95 cDNA (Golstein et al, 1995) were digested with Hind III and Xhol, respectively. ${ }^{32}$ P-UTP-labeled anti-sense RNA probes were generated using the T3 MAXIscript kit from Ambion, according to the manufacturers protoco. The resulting $770 \mathrm{bp}$ (fap-1) and $620 \mathrm{bp}$ (CD95) probes were gel purified and hybridized with $20 \mu \mathrm{g}$ total RNA prior to digestion with RNAse T1/A1. The protected fragments were identified by urea/SDS-PAGE and autoradiography. Beta-actin was used as internal standard (not shown).

\section{Flow cytometry analyses}

Cells $\left(1 \times 10^{6}\right)$ were centrifuged and resuspended in phycoerythrin (PE) conjugated anti-CD95 (clone Jo2) or control PE conjugated Hamster IgG in PBS with $2 \%$ Fetal Bovine Serum and $0.01 \%$ sodium azide (staining buffer) for $30 \mathrm{~min}$ at $4^{\circ} \mathrm{C}$. Following two washes with the staining buffer, the cells were analyzed using a FACScan (Becton Dickinson, Mountain View, CA) instrument with standard equipment and settings.

Apoptosis was quantified with flow cytometry as described in Figure 1 (Swat et al, 1991). All of the apoptotic cells present in region 2 
of the flow scattergram shown in Figure 1 also stained with the TUNEL assay (Gorczyca et al, 1993), and the percentage of apoptotic S49.1 cells determined using either of the two methods corresponded well (data not shown).

\section{Acknowledgements}

This work was partly supported by an American Cancer Society Institutional Grant to the UCSD Cancer Center and the National Institutes of Health grant GM52735 to DRG. We are grateful to Dr Jonathan Treisman (Treisman et al, 1995) for the pSAMEN retroviral vector, Drs Stanislaw Krajewski and John C Reed for the anti-human Bcl$x$ antibody (Krajewski et al, 1994), Drs Shinichi Takayama and John C Reed (Takayama et al, 1995) for the bag-1 cDNA probe and anti-Bag-1 antibody, Drs Takaaki Sato and John C Reed for the fap-1 cDNA probe, and Pierre Golstein (Rouvier, Luciani et al, 1993) for the murine fas cDNA clone.

\section{References}

Boise LH, Gonzalez-Garcia M, Postema CE, Ding L, Lindsten T, Turka LA, Mao X Nunez $G$ and Thompson CB (1993) bcl-x, a bcl-2 related gene that functions as a dominant regulator of apoptotic cell death. Cell 74: 597-608

Boise LH, Minn AJ, Noel PJ, June CH, Accavitti MA, Lindsten T and Thompson CB (1995) CD28 costimulation can promote T cell survival by enhancing the expression of $\mathrm{Bcl}-\mathrm{xL}$. Immunity 3: 87-98

Broome HE, Dargan CM, Krajewski S and Reed JC (1995) Expression of Bcl-2, Bcl-x, and Bax after T cell activation and IL-2 withdrawal. J. Immunol. 155: 2311-2317

Brunner T, Mogil RJ, LaFace D, Yoo NJ, Mahboubi A, Echeverri F, Martin SJ, Force WR, Lynch DH, Ware CF and Green DR (1995) Cell-autonomous Fas (CD95)/ Fas-ligand interaction mediates activatiion-induced apoptosis in T-cell hybridomas. Nature 373: $441-444$

Chao DT, Linette GP, Boise LH, White LS, Thompson CB and Korsmeyer SJ (1995) $\mathrm{Bcl}-\mathrm{XL}$ and Bcl-2 repress a common pathway of cell death. J. Exp. Med. 182: $821-828$

Chiu VK, Walsh CM, Liu CC, Reed JC and Clark WR (1995) Bcl-2 blocks degranulation but not fas-based cell-mediated cytotoxicity. J. Immunol. 154: 2023-2032

Enari M, Hug H and Nagata S (1995) Involvement of an ICE-like protease in Fasmediated apoptosis. Nature 375: 78-81

Golstein P, Marguet D and Depraetere V (1995) Homology between reaper and the cell death domains of Fas and TNFR1 [letter]. Cell 81: 185-186

Gorczyca W, Gong J, Ardelt B, Traganos F and Darzynkiewicz Z (1993) The cell cycle related differences in susceptibility of $\mathrm{HL}-60$ cells to apoptosis induced by various antitumor agents. Cancer Res. 53: 3186-3192

Itoh N, Tsujimoto Y and Nagata S (1993) Effect of bcl-2 on Fas antigen-mediated cell death. J. Immunol. 151: $621-627$

Itoh N, Yonehara S, Ishii A, Yonehara M, Mizushima S, Sameshima M, Hase A, Seto Y and Nagata S (1991) The polypeptide encoded by the cDNA for human cell surface antigen Fas can mediate apoptosis. Cell 66: 233-243

Kingston RE (1990) Transfection of DNA into eukaryotic cells. In Current Protocols in Molecular Biology, Struhl K, Ausubel FM, Brent R, Kingson RE, Moore DD, Seidman JG and Smith JA, eds. (New York, Wiley \& Sons) pp. 9.1.1

Klas C, Debatin KM, Jonker RR and Krammer PH (1993) Activation interferes with the APO-1 pathway in mature human T cells. Int. Immunol. 5: 625 -630
Krajewski S, Krajewski M, Shabaik A, Wang HG, Irie S, Fong L and Reed JC (1994) Immunohistochemical analysis of in vivo patterns of $\mathrm{Bcl}-\mathrm{X}$ expression. Cancer Res. 54: 5501-5507

Landau NR and Littman DR (1992) Packaging system for rapid production of murine leukemia virus vectors with variable tropism. J. Virol. 66: 5110-5113

Memon SA, Moreno MB, Petrak D and Zacharchuk CM (1995) Bcl-2 blocks glucocorticoid-but notFas- or activation-induced apoptosis in a T cell hybridoma. J. Immunol. 155: 4644-4652

Miyashita T and Reed JC (1992) bcl-2 gene transfer increases relative resistance of S49.1 and WEHI7.2 lymphoid cells to cell death and DNA fragmentation induced by glucocorticoids and multiple chemotherapeutic drugs. Cancer Res. 52 : $5407-5411$

Muzio M, Chinnaiyan AM, Kischkel FC, O'Rourke K, Shevchenko A, Ni J, Scaffidi C, Bretz JD, Zhang M, Gentz R, Mann M, Krammer PH, Peter ME and Dixit VM (1996) FLICE, a novel FADD-homologous ICE/CED-3-like protease, is recruited to the CD95 (Fas/Apo-1) death-inducing signaling complex. Cell 85: 817-827

Nishimura Y, Ishii A, Kobayashi Y, Yamasaki Y and Yonehara S (1995) Expression and function of mouse Fas antigen on immature and mature T cells. J. Immunol. 154: $4395-4403$

Owen-Schaub LB, Yonehara S, Crump WL and Grimm EA (1992) DNA fragmentation and cell death is selectively triggered in activated human lymphocytes by Fas antigen engagement. Cell Immunol. 140: 197-205

Reiux-Laucat F, Le Deist F, Hivroz C, Roberts IA, Debatin KM, Fischer A and de Villartay JP (1995) Mutations in Fas associated with human lymphoproliferative syndrome and autoimmunity. Science 268: 1347-1349

RouvierE, Luciani MF and Golstein P (1993) Fas involvement in Ca(2+)-independen T cell-mediated cytotoxicity. J. Exp. Med. 177: 195-200

Russell JH, Rush B, Weaver C and Wang R (1993) Mature T cells of autoimmune lpr/ Ipr mice have a defect in antigen-stimulated suicide. Proc. Natl. Acad. Sci. U.S.A. 90: $4409-4413$

Sato T, Irie S, Kitada S and Reed JC (1995) FAP-1: a protein tyrosine phosphatase that associates with Fas. Science 268: 411-415

Swat W, Ignatowicz $L$ and Kisielow P (1991) Detection of apoptosis of immature CD4+8+ thymocytes by flow cytometry. J. Immunol. Methods 137: 79-87

Takayama S, Sato T, Krajewski S, Kochel K, Irie S, Millan JA and Reed JC (1995) Cloning and functional analysis of BAG-1: a novel Bcl-2-binding protein with anticell death activity. Cell 80: 279-284

Tewari M and Dixit VM (1995) Fas- and tumor necrosis factor-induced apoptosis is inhibited by the poxvirus crmA gene product. J. Biol. Chem. 270: 3255-3260

Trauth BC, Klas C, Peters AM, Matzku S, Moller P, FalkW, Debatin KM and Krammer $\mathrm{PH}$ (1989) Monoclonal antibody-mediated tumor regression by induction of apoptosis. Science 245: 301-305

Treisman J, Hwu P, Minamoto S, Shafer GE, Cowherd R, Morgan RA and Rosenberg SA (1995) Interleukin-2-transduced lymphocytes grow in an autocrine fashion and remain responsive to antigen. Blood 85: 139-145

Tsujimoto Y and Croce CM (1986) Analysis of the structure, transcripts, and protein products of bcl-2, the gene involved in human follicular lymphoma. Proc. Natl. Acad. Sci. U.S.A. 83: 5214-5218

Tucek-Szabo CL, Andjelic S, Lacy E, Elkon KB and Nikolic-Zugic J (1996) Surface T cell fas receptor/CD95 regulation, in vivo activation, and apoptosis. J. Immunol. 156: $192-200$

Watanabe-Fukunaga R, Brannan Cl, Copeland NG, Jenkins NA and Nagata S (1992) Lymphoproliferation disorder in mice explained by defects in Fas antigen that mediates apoptosis. Nature 356: $314-317$

Weinroth SE, MacLeod CL, Minning L and Hays EF (1985) Genetic complexity of glucocorticoid-induced lysis of murine T-lymphoma cells. Cancer Res. 45: $4804-4809$

Zheng L, Fisher G, Miller RE, Peschon J, Lynch DH and Lenardo MJ (1995) Induction of apoptosis in mature T cells by tumour necrosis factor. Nature $377: 348-351$ 